\title{
ENGLISH APPELLATE PROCEDURE
}

\author{
Samuel O. Clark, JR.
}

Strangely enough, the wave of procedural reform in the United States, started by the Field Code of 1848 in New York, embraced only reforms in pleading and other matters preliminary to trial. The English people, on the other hand, in their great reform of $1873^{1}$ reorganized their entire procedural system, and as a result, the English appellate system differs in many important respects from that of any of the American states. Before considering the appellate procedure, the English court structure will be discussed briefly.

\section{ENGLISH COURTS}

The English Court system consists of the following principal courts : Petty Session, Quarter Session, County Courts, Supreme Court of Judicature with its two branches, the High Court of Justice and the Court of Appeal, and the House of Lords.

\section{Petty Session and Quarter Session}

The Courts of Petty Session are very similar to our Justice of the Peace Courts. These courts exercise jurisdiction over a limited class of actions and are limited as to the amount of recovery. 2 The Courts of Quarter Session hear appeals from the Courts of Petty Session and also have a limited jurisdiction in criminal matters.

\section{County Courts}

Judged by the comparative number of actions brought, the County Courts handle the bulk of England's litigation. The number of actions brought in County Courts for the year 1926 was 897,895 , while during the same period only 106,738 actions were initiated in the High Court. ${ }^{3}$ The County Courts have jurisdiction over a wide variety of actions, but their jurisdiction as to amount is limited in the main to $£ 100 .^{4}$ An appeal lies to a

1 Judicature Act, 36-37 VICr. c. 66 (1873).

2 See Hibbert, LaW of Procenure (2d ed. 1921), listing matters over which the court has jurisdiction.

${ }^{3}$ Civil Judicial Statistics for England and Wales (1926).

4 County Court Acts, 51 \& 52 VICT. c. 43 (1888) ; 3 EDw. VII, c. 42 (1903); 
Divisional Court of the High Court of Justice, except that in a few specialized actions an appeal is taken directly to the Court of Appeal. ${ }^{6}$

\section{Supreme Court of Judicature}

This court, although not handling as many actions as the County Courts, may well be termed the most important court of England, handling as it does both the trial in the first instance of the more important cases and the appeals therefrom. It also hears appeals from inferior courts. The court is divided into two branches, the High Court of Justice and the Court of Appeal.

(a) High Court of Justice. The High Court of Justice has practically unlimited jurisdiction over original actions, ${ }^{7}$ but a party suing in this court may be penalized with heavy costs if the action is within the jurisdiction of one of the inferior courts. ${ }^{5}$ Appeals from the High Court are heard by the Court of Appeal.

The High Court is divided into three divisions: King's Bench, Chancery, and Probate, Divorce, and Admiralty. Each division has its own particular work to do. In general, the Chancery Division handles equitable matters, the Probate, Divorce, and Admiralty Division deals with matters coinciding with its name, and the King's Bench Division handles all others. But this classification is not drawn upon strictly jurisdictional lines, as an action brought in a wrong division may be easily transferred to the proper one. No technical distinctions between law and equity are retained. The distribution of actions among the three divisions is designed rather to develop trial judges who are specialists in one general type of action. ${ }^{9}$

Each division of the High Court may form a Divisional Court, consisting ordinarily of two judges, to hear appeals from inferior courts. ${ }^{10}$ Further appeals may then be had to the Court of

9 \& 10 GEo. V, c. 73 (1919). See HIBberT, op. cit. supra note 2 , at 2 et seq., setting out the jurisdiction of this court.

5 If the amount involved in the action does not exceed $£ 20$, there is no appeal without first obtaining leave from the County Court judge. $\delta 1 \& 52$ VICT. c. $43, \S 120$ (1888).

${ }^{6}$ For a list of these actions see Axwual Practice (1928) 1171. Other courts exercising limited and local jurisdiction such as the Mayor's and City of London Court and the University Court will not be discused. They are described in HIBBERT, op. cit. supra note 2, at 6.

${ }^{7}$ For limitations on the jurisdiction of the High Court, see BaTy, Suprease Court Practice (2d ed. 1924) 1.

8 Administration of Justice Act, $15 \& 16$ Geo. V, c. 28, \$ 20 (1925), amending $\S 11$ of County Courts Act of 1919.

9 See Kales, The English Judicatuie Acts (1921) 4 Ax. Jud. Soc. J. $1: \%$.

10 Judicature Act, $15 \& 16$ Geo. V, c. $49, \S 63$ (1925). Further duties of the Divisional Courts are set out in Order 59, rule 1. Divisional Courts 
Appeal only with leave."11 The appellate procedure of the Divisional Courts will not be examined, since it follows in the main the procedure of the Court of Appeal.12

(b) Court of Appeal. This court, which forms the other branch of the Supreme Court of Judicature, corresponds to the typical American state court of last resort. It consists of five judges known as Lord Justices of Appeal, ${ }^{13}$ and certain ex-officio members who may sit with the Court of Appeal if an exigency arises. ${ }^{14}$ Also, the Lord Chancellor has the power to appoint any justice of the High Court to sit temporarily on the Court of Appeal. ${ }^{15}$ To qualify for appointment as a Lord Justice of Appeal, the appointee must either be a judge of the High Court or have had not less than fifteen years standing as a barrister., ${ }^{10}$ Thus actual experience with trial work is assured.

For the speedier dispatch of business the Court of Appeal is authorized to sit in three divisions, ${ }^{17}$ although in practice it seems that two divisions are sufficient to handle the cases pending. The idea of specialization seems to be carried out here, as appeals from the King's Bench Division ordinarily go to one division and appeals from Chancery go to the other. ${ }^{18}$ The Lord Chancellor has the power to increase or decrease the number of appeal divisions in accordance with the number of appeals pending. ${ }^{19}$ All appeals are heard by three judges, with two exceptions: appeals from interlocutory orders are heard by two judges only; ${ }^{20}$ and all other appeals may be heard by only two judges if both parties so agree.21

\section{House of Lords}

If a litigant can afford to risk the heavy costs involved, there

are rarely formed in the Chancery Division. BATY, op. cit. supra note 7, at 145.

If the two judges are divided in opinion, the decision below stands. ANNUAL Practice (1928) 1230.

$1115 \& 16$ Geo. V, c. $49, \S 31$ (h) (1925).

12 Order 59, rule 17 provides that "the rules for the time being in force with respect to appeals from the High Court to the Court of Appeal shall, so far as practicable, apply to and govern appeals ... to the High Court."

13 Judicature Act, 15 \& 16 Geo. V, c. $49, \S 6(1,3)$ (1925):

14 Ibid. \& 6 (2).

15 Ibid. $\S \S 7,8$.

${ }^{16}$ Ibid. $\$ 9$ (2).

17 Ibid. $\$ 68$ (3).

18 Kales, op. cit. supra note 9 , at 136.

19 Judicature Act, $15 \& 16$ Geo. V, c. 49 , \$§ 6-8 (1) (1925).

20 Ibid.

21 Ibid. $\$ 68$ (5). If the two judges disagree, the case will be re-argued before three judges upon the application of any party. 
is a further appeal to the House of Lords.?2 Appeals are heard by the Lord Chancellor, six Lords of Appeal in Ordinary, and any peer of Parliament who has held high judicial affice..3 Although the lay peers are not syecifically excluded from the hearing of the appeal, as a matter of practice they have not taken part for almost two centuries.

As the House of Lords while acting as a court is an institution peculiar to England, its procedure will not be discussed.: Suffice to say that the preparation of a case for appeal is a very complicated and technical problem. Possibly the desire to discourage appeals to the House of Lords has induced a retention of its cumbersome procedure. ${ }^{25}$

\section{Rule Maling Committce}

A feature of the English system is the extensive rule making powers given the judges. To avoid the rigidity of legislative enactments on purely procedural questions, the statutes cover only the more general matters such as the number of judges, the make-up of the courts, and the jurisdiction of each court, the details being left to the rule making committee.25 The statutory provisions regarding the Court of Appeal are illustrative. The number and qualifications of the Lord Justice of Appeal, the restrictions on appeal to the Court of Appeal, and the general jurisdiction of the court are covered by provisions of the Judicature Act.2z The Act then provides further that rules may be enacted prescribing the procedure on appeal,as and pursuant to this twenty-one rules have been drawn.20

22 Appellate Jurisdiction Act, $39 \& 40$ Vicr. c. 59, § 3 (1876). An appeal to the House of Lords was abolished in 1873 but reinstated in 1876.

23 Appellate Jurisdiction Act, 39 \& 40 VrcT. c. 59, § 5 (1876).

24 The procedure on appeal to the House of Lords is deseribed brienly in BATY, op. cit. supra note 7 , at 153.

${ }^{25}$ The English appellate system may be criticized for granting a right in most cases to double and in some instances to triple appeals. A system which involves double appeals has been criticised as an economic waste. See Sunderland, The Problem of Appellate Review (1927) 5 TEx. L. REx: 126, 134.

26 This committee is composed of the Lord Chancellor, the Lord Chief Justice, the Master of the Rolls, the President of the Probate Division, four other judges of the Supreme Court, two practicing barristers, and two practicing solicitors. Judicature Act, $15 \& 16$ GEo. V, c. $49, \S 99$ (4) (1925). Ibid. $\S 99$ (1) provides for the powers of this committee. Its work is described in Rosenbaum, RULe Making Authority in the Eiggusir SUPREME COURT (1917).

2ะ 15 \& 16 GEO. V, C. 49 , §§ 6-17, 26-32 (1925).

${ }^{28}$ Ibid. § 99 ( 1 b).

29 These rules with annotation may be found under Order 58 either in King and Ball's ANnual Practice (1928) or in ChitTy and Marhis' YEARLY PRACTICE (1928). 


\section{Administrative Control}

Another distinctive feature is the placing of the courts under administrative control. Each division of the High Court has a judge who acts as its governing head. Thus the Lord Chancellor is President of the Chancery Division, the Lord Chief Justice is President of the King's Bench Division, and the Division of Probate, Divorce, and Admiralty has its president. The Lord Chancellor is also President of the Court of Appeal. These presidents may sit as ex-officio members of the Court of Appeal. They are given more power than is usually accorded a Chief Justice of a court of last resort in the United States. Their duties in part consist of overseeing the distribution of business in their division, and in promoting general efficiency in the handling of litigation. ${ }^{30}$

\section{TRIAL PRACTICE}

Although not within the direct scope of this article, there are several factors in the English trial practice which are conducive to speed and efficiency in the disposition of litigation, which should be noticed in passing. Chief among these are: the simplified pleading, the use of the summary judgment, and the employment of masters to dispose of non-contentious litigation, to decide questions of pleading, to form the issues, and to clear up other matters preliminary to trial. The actual trial is characterised by the speedy selection of the jury, a common sense view toward the rules of evidence, ${ }^{31}$ and the skill with which the English barristers, specialists in trial work, conduct their cases. ${ }^{32}$

\section{Judge's Notes of the Evidence}

The English method of recording the oral testimony given at trial will be discussed at some length because of its connection with appellate procedure. In England there are no official court stenographers. The judge takes notes of the oral testimony and these notes form the only record of the testimony. ${ }^{33}$ The judge refers to his notes in summing up the evidence and in making findings of fact if he is called upon to do so, and his notes also

so The advantages of the English system of administrative control are discussed by Kales, op. cit. supra note 9 , at 136 .

31 An American writer reports that in 1924 no cases from the King's Bench Division were reversed for error in admitting or excluding evidence. Sunderland, Modern English Legal Procedure (1926) 4 TEx. L. REv. 273, 291.

32 These and other features of English Procedure are described by Sunderland, op. cit. supra note 31, and by Higgins, English Courts and Procedure (1924) 7 AM. JUd. Soc. J. 185.

${ }^{33}$ See Simmons v. Crossley, [1922] 2 K. B. 95, 98. 
form the record of the evidence on appeal. If one of the parties wishes a more detailed record, he must personally, and at his own expense, provide a private stenographer for this purpose. This is usually done when a party feels that the testimony will be so long or so complicated that the judge's notes will not form a sufficient record. The use on appeal of testimony recorded in this manner will be discussed later. The judge may upon consent of both parties dispense with the taking of notes and accept the transcribed report of a stenographer furnished by one or both of the parties as the official record of the evidence.st

At first impression it seems undesirable to place such an irksome task on a highly paid judge. And the progress of the trial is probably delayed to some extent. But on the other hand, the judge and jury have more time to assimilate the evidence, and the judge is forced to give closer attention to the proceedings. The plan may to some extent improve the character of the oral testimony, since the judge, in view of his task of recording the evidence, would not be inclined to tolerate quibbling or irrelevant questions. ${ }^{35}$

\section{JURISDICTION OF THE COURT OF APPEAL}

\section{General}

In comparing the powers of the English Court of Appeal with those of the typical court of last resort in the United States, the differences in viewpoint as to the function of an appellate court must be kept constantly in mind. The attitude in the United States is to regard an appeal only as a process for the detection of errors, as the appellate court is a reviewing body sitting in judgment on the acts of the trial judge. If there is prejudicial error, a new trial follows as a matter of course in most cases. The English attitude, on the other hand, is to provide a rehearing of the action for an unsatisfied litigant, not merely for the detection of error, but mainly for the purpose of finally disposing of the case. ${ }^{36}$ To this end the Judicature Act provides:

"For all the purposes of and incidental to the hearing and

34 This was done in Seal v. Turner, [1915] 3 K. B. 194.

35 On the subject of judges' notes see Higgins, op. cit. supre note 32 , at 222. This author, writing in 1914, said, "There has been considerable agita. tion for official shorthand reporters instead of note taking by the judge, but without results so far." Swith, J., also thinks official stenographers are desirable. See Simmons v. Crossley, supra note 93, at 98. But at an earlier period, Jessel, MI. R., criticized the use of stenographic notes. See Earl de la Warr v. Miles, 19 Ch. D. 80,82 (1881).

3 is This difference in attitude is well brought out by Profescor Sunderland, op. cit. sicpra note 25 , at 139 . 
determination of any appeal ... the Court of Appeal shall have all the power, authority and jurisdiction of the High Court."

In other words, the Court of Appeal besides its jurisdiction to hear appeals has all the powers of a trial court. A rule of court ${ }^{38}$ provides:

"The Court of Appeal shall have all the powers and duties as to amendment ${ }^{39}$ and otherwise of the High Court, together with full discretionary power to receive further evidence upon questions of fact. ${ }^{40}$. . . The Court of Appeal shall have power to draw inferences of fact ${ }^{41}$ and to give any judgment and malie any order which ought to have been made, and to malie such further or other order as the case may require.42 The powers aforesaid may be exercised by the said court, notwithstanding that the notice of appeal may be that part only of the decision may be reversed or varied, and such powers may also be exercised in favour of all or any of the respondents or parties, although such respondents or parties may not have appealed from or complained of the decision. ${ }^{43}$ The Court of Appeal shall have power to make such order as to the whole or any part of the costs of appeal as may be just." "4t (Italics ours)

The Court of Appeal may also consider points raised for the first

$3715 \& 16$ GEo. V, c. $49, \S 27$ (1) (1925).

38 Order 58 , rule 4.

39 Order 28, rules 1-13 cover the powers of the High Court as to amendments. In William v. Preston, $20 \mathrm{Ch}$. D. 672 (1882), the Court of Appeal permitted the defendant to amend by withdrawing her defense below which had been introduced through the fraud of her solicitor, and by substituting a new defense. The Court of Appeal on hearing the amended defense reversed the judgment below and entered final judgment for the defendant. But in Hipgrove v. Case, $28 \mathrm{Ch}$. D. 356 (1885), the plaintiff, suing for specific performance, was not permitted to amend to claim damages only, as the Court of Appeal believed the plaintiff was negligent in not amending below.

40 This will be considered infra.

41 In non-jury cases the Court of Appeal may make findings of fact at variance with those of the court below, but it grants due deference to the opinion of the trial judge when the credibility of the witnesses is concerned. Coghlan v. Cumberland, 1 Ch. D. 704 (1898). As to jury cases, see infra.

42 The italicized words give the English Court of Appeal its extensive and distinctive powers. For example, the Court of Appeal may entar final judgment for the appellant although he appealed from an interlocutory order. Miller v. Pilling, 9 Q. B. D. 736 (1881).

${ }^{43}$ In Attorney-General v. Simpson, [1901] 2 Ch. 671, 720, the judgment was altered in favor of the respondent although he had entered no crossappeal.

44 See Order 65, rule 1. The Court of Appeal may under some circumstances deprive a successful appellant of his costs. Ex parte Cooper, $10 \mathrm{Ch}$. D. 313, 322 (1878). Or may dismiss an appeal without costs. Ex parte Welton, 17 Ch. D. 746, 758 (1881). See other cases cited in ANNUAL PRACTICE (1928) 1193 et seg. 
time on appeal.s5 With the exception of the power to draw inferences of fact and to make an order as to costs, the above powers are almost invariably denied the appellate courts in the United States. These extensive powers are given to the English Court of Appeal for the obvious purpose of terminating the particular action appealed, thus averting the hardship of a new trial. The Court of Appeal has, of course, the power to grant a new trial but this will be done only when, as a matter of justice and convenience, the case should be retired below.

\section{Further Evidence on Appcal}

As another means of avoiding new trials, the Court of Apneal may hear further evidence on appeal. $\mathrm{A}$ party has an absolute right to introduce such evidence when the appeal is taken from an interlocutory order, or when the evidence relates to matters which occurred after the date of the decision below: ir On all other appeals such evidence may be introduced only with the leave of the Court of Appeal.s" But after a trial below on the merits, leave will not be given to a party who intent:onslly: or negligently failed to produce the evidence below. ${ }^{3}$ Lenve has been granted when the court below should have admitted the evidence, ${ }^{50}$ and when the evidence was not known to exist at the time of the trial.51 The evidence may be introduced by oral testimony before the Court of Appeal itself, s2 by affidavit, by deposition, or by reference to an expert for inquiry and report. ${ }^{3}$ The appellant should give notice to the respondent that he will apply

45 It lies vithin the discretion of the Court of Appeal whether to listen to a point raised for the first time on appeal. In view of the possibility of injustice to the respondent this power will be exereised very sparingly. If the point is heard, the appellant, even if successful, is often deprivel of his costs. See cases cited in Annual Practice (1928) 1108.

16 Michigan gives its supreme court this power. "The Supreme Court may, at any time, in accordance with and for the speedy furtheranec of justice in any suit, either in law or in cquity, call upon the partics to such suit, or any witness thereto, to testify orally in open court. . . ." MICH. CoMrP. LAws (Cahill, 1915) \& 12034. This power was exerciscd in Schroeder v. Boyce, 127 Mich. 33,86 N. W. 387 (1901). The general subject is discussed in Comment (1929) 38 YALE L. J. 971.

47 Order 58, rule 4.

48 Ibid.

49 Nash v. Bockford Rural Council, [1917] 1 K. B. 881; Sanders v. Sanders, 19 Ch. D. 373,380 (1881).

50 In re Chennell, 8 Ch. D. 492, 504 (1878).

51 Evans v. Benyon, 37 Ch. D. 329, 339 (1887).

52 This was done in Evans v. Benyon, supra note 51, and in In re National Debenture Corp., [1891] 2 Ch. 505, 516.

53 See Yearly Practice (1928) 1164. 
for leave to adduce fresh evidence."s But where a party wishes to examine witnesses before the Court of Appeal, he must move the Court of Appeal and obtain the necessary leave before the hearing on appeal..$^{55}$

\section{When an Appeal Lies}

There is not in England an unlimited right of appeal to the Court of Appeal. ${ }^{56}$ No appeal lies in criminal matters. ${ }^{57}$ On the civil side a few comparatively unimportant matters are not appealable, such as orders granting an extension of time, or the right to defend an action. ${ }^{5 s}$ Other matters are not appealable without leave. This restriction applies to all decisions on appeals to a Divisional Court.59 In this connection it is to be noted that an appeal from a decision of a judge of the High Court sitting in chambers is taken to a Divisional Court and not to the Court of Appeal,"0 but an important exception provides that a decision so made on questions of practice and procedure shall go directly to the Court of Appeal in order to cut down the possibility of double appeals on these matters. ${ }^{61}$

The usual practice in the United States is to bar an appeal on questions of fact, at least in non-equity cases, but no such restriction exists in England. Likewise in most states there is no appeal

\footnotetext{
54 See In re Chennell, supra note 50, at 505. For form of this notice seo ChITTY's Forms (15th ed. 1923) 615.

5 Dicks v. Brooks, 13 Ch. D. 652 (1880).

${ }^{56} \mathrm{By}$ placing restrictions on the right of appeal an appellate court is relieved of hearing cases which are not deemed worthy of a rehearing. The disadvantage of such restrictions is that much of the time of the appellate court is required to determine when the restriction applies. See Sunderland, op. cit. supra note 25.

57 Judicature Act, 15 \& 16 Geo. V, c. 49, § 31 (1a) (1925). Until 1907 there was no appeal from a conviction in a criminal case. See 1 HoLDsworth, A History of ENGLish Law (3d ed. 1922) 217. The miscarriage of justice which sometimes resulted led to the establishment of the Court of Criminal Appeal, consisting of the Lord Chief Justice and eight judges from the King's Bench Division of the High Court. The decision of this court is final unless the case involves a point of law of exceptional public importance, in which case an appeal may be certified to the House of Lords. Criminal Appeal Act, 7 EDw. VII, c. 23 (1907). By a strange anomaly, the court lacks the power of appellate courts in civil cases to grant a new trial, so if prejudicial error is found in the conviction, the defendant goes free.

58 Judicature Act, $15 \& 16$ GEo. V, c. 49, § 31 (1) (1925); and see ANNuAL PRACTICE (1928) 1171, 1172.

5o Judicature Act, $15 \& 16$ GEo. V, c. $49, \S 31$ (1f) (1925).

no Order 54, rule 23.

61 Judicature Act, 15 \& 16 Geo. V, c. $49, \S 31$ (3) (1923). As to what constitutes questions of practice and procedure, see cases cited ANNUAL PraCTICE (1928) 1019.
} 
from interlocutory orders, ${ }^{62}$ while in England there are no restrictions on appeals from certain interlocutory orders, while others are appealable only with leave. ${ }^{\text {s }}$ The interlocutory orders appealable without leave inciude, inter alin, order's granting or denying an injunction, and orders affecting the liberty of subjects or the custody of infants. ${ }^{\text {at }}$ In the above cases leave is obtained by first applying to the judge or court which made the decision in question, and if leave is refused, then by applying to the Court of Appeal for leave. ${ }^{65}$ This is by way of an ex parte motion and not an appeal from the order denying leave.

A litigant dissatisfied with an order or judgment may appeal subject to the restrictions noted above, or, if there has been a trial either with or without a jury, he may apply to the Court of Appeal for a new trial. Contrary to the usual practice in the United States, an application for a new trial is not made to the trial judge, but goes directly to the Court of Appeal."; The powers of the Court of Appeal on hearing an application for a new trial are the same as on hearing an appenl.s In both instances the court may either grant a new trial or enter judgment on the merits. ${ }^{\circ}$ A rule of court provides that, on application for a new trial,

“... the court may draw all inferences of fact not inconsistent with the finding of the jury, and, if satisfied that it has before it all the materials necessary for finally determining the question in dispute, or any of them, or for awarding any relief sought, give judgment accordingly. ..." 70

The court is reluctant to upset the jury's verdict if there was sufficient evidence to go to the jury, ${ }^{71}$ but it may, if it thinks the jury's verdict is perverse, and if all the facts are clear, enter

62 See (1923) 34 YaLE L. J. 905. As to the relative advantages and disadvantages of appeals from interlocutory orders, sce Sunderland, op. cit. supra note 25 , at 127 .

63 Judicature Act, 15 \& 16 Geo. V, c. 49, \$ \$1 (1c) (1925). There scems to be considerable litigation concerning the distinction between interlacutury and final orders. See cases cited Yearly Prictice (1928) 1185 et ar q.

E4 Judicature Act, $15 \& 16$ GEo. V, c. 49 , \$ $\$ 1$ (1i) (1925).

65 Order 58, rule 17.

66 See Order 58, rule 10 and ANnual Prictice (1928) 1174.

Gr Judicature Act, 15 \& 16 GEo. V, c. 49, $\$ 30$ (1) (1925); Order 89 , rule 1.

es Order 39, rule 2 provides, "On the hearing of such application (for a new trial), the Court of Appeal shall have all such powers as are cxercisable by it upon hearing of an appeal."

69 Order 40 , rule 10 ; Order 58 , rule 5 . In view of this identity of powers, the desirability of providing a separate method of moving for a new trial is open to some question.

70 Order 40, rule 10.

il Brewster v. Durrand, [1880] W. N. 27; Milessich v. Lloyds, 46 L. J. 404 (1877). 
final judgment for the appellant. ${ }^{72}$ But if all the facts are not clear, or further evidence could be adduced which should go to the jury, there will be a new trial. ${ }^{73}$ As a corollary to the use of the special verdict, the Court of Appeal may affirm the verdict as to certain issues and reverse as to others. ${ }^{74}$ As the procedure in making an application for a new trial is in general the same as in taking an appeal, ${ }^{75}$ applications for a new trial will not be discussed further, except to note such differences as appear.

\section{MECHANICS OF APPEAL}

Order 58 , rule 1 , provides that "all appeals shall be by way of rehearing, ${ }^{76}$ and shall be brought by notice of motion in a summary way and no petition, case, or other formal proceeding other than such notice shall be necessary." Hence all the impediments connected with the typical American appellate system are abolished. There are no writs of certiorari, no writs of error, no bills of exceptions, no assignments of error. The evidence is not reduced to narrative form; there are no formal findings by the court as in Conecticut; or a formal "case on appeal" to be thrashed out between counsel and the trial judge. The appealing party merely takes the following steps:

1. Serves notice of motion for a rehearing on the opposite party.

2. Enters the appeals with the proper officer of the Court of Appeals.

3. Files the documents necessary for the determination of the appeal with the Court of Appeals.

4. Delivers the argument on appeal.

These items will each be described in detail. It will appear

72 Hamilton v. Johnson, 5 Q. B. D. 263 (1879); Bobbett v. South Eastern Ry., 9 Q. B. D. 424, 431 (1882); Chapleo v. Brunswick Building Socicty, 6 Q. B. D. 696, 714 (1881) ; Skeate v. Slaters, [1914] 2 K. B. 429, 439.

${ }_{73}$ Morton v. Palmer, 51 L. J. 307 (1882); Clark v. Molyneux, 3 Q. B. D. 237, 249 (1877).

74 Order 39 , rule 7.

75 "Every such application shall be brought before the Court of Appeal in like manner as an appeal ...." Order 39, rule 2.

76 The English judges place considerable emphasis on the fact that their appellate review is by way of a rehearing and not by a technical appeal. "All appeals are by way of rehearing, that is, by trial over again, on tho evidence used in the Court below; but there is special power to receive further evidence." Jessel, M. R., in In re Chennell, supra note 50, at 504. "On an appeal strictly so called, such a judgment can only be given as ought to have been given at the original hearing; but on a rehearing such a judgment may be given as ought to be given if the case came at that time before the Court of first instance." Jessel, M. R., in Quilter v. Mapleson, 9 Q. B. D. 672,676 (1882). 
that items 1 to 3 inclusive are mainly routine and may be performed by clerks rather than lawyers. This is in itself an advantage over our more complicated system where the preparation of a "case on appeal" usually requires the services of a trained lawyer.

\section{Notice of Motion}

The notice of the motion for a rehearing merely informs the other party that there will be an appeal."7 The notice must state whether all or part of the judgment is appealed from, and in the latter case, it must specify what part. The notice specifies the day on which the appeal will be heard. This date must be at least fourteen days after service of notice on the respondent in case of an appeal from final judgment, and four days in case of an appeal from an interlocutory order::8 Of course the appeal will probably be heard after the day stated, as it ordinarily must await its proper order, but it cannot be heard before. The notice need not state the grounds on which the appeal is based, and if the grounds are stated, the appellant is not confined to them in his argument. ${ }^{73}$

The appellant must serve notice upon the respondent within fourteen days in case of an appeal from an interlocutory order, and within six weeks in case of an appeal from a final judgment. ${ }^{80}$ But these periods may be extended by leave either of the court making the decision appealed from or by the Court of Appeal.s1 This is a salutary rule designed to prevent the injustice which results when a rigid provision as to time is applied to all situations. But leave is not granted unless the court is satisfied that a good reason for the delay has been advanced. ${ }^{82}$

${ }_{77}$ Order 58 , rule 1. For form of this notice, see CurTty, op. cit. supre note 54 , at 610 .

78 Order 58 , rule 3 ; Order 59 , rule 4.

79 Sunderland, op. cit. supra note 31 , at 290. But on an application for a new trial, the grounds on which the application is based must be stated if there has been a jury trial, but not if there has been a court trial. Order 39 , rule 3.

so Order 58, rule 15 . Notice of motion for a new trial must be served within six weeks after the trial. Order 39 , rule 4 .

si Order 58, rule 15. As to extensions of time in general, Order 64, rule 7 provides: "A Court or a Judge shall have power to enlarge or abridge the time appointed by these rules ... upon such terms as the justice of the eare may require, and any such enlargement may be ordered although the application for the same is not made until after the expiration of the time appointed or allowed." For comment on the desirability of such a provision, see Higgins, op. cit. supra note 32, at 206. There is no appeal from an order granting an extension of time to appeal. Judicature Act, $15 \& 16$ GEo. V, c. 49 , § 31 (1b) (1925). For form of the motion for an extension of time, see CHITTY, op. cit. supra note 54, at 613 .

82 For cases, see Annuar Practice (1928) 1212. 


\section{Entry of the Appeal}

To "enter" an appeal, the appealing party goes to the officer of the Court of Appeal, corresponding with our clerk of court, and leaves with him a copy of the notice of appeal to be filed. ${ }^{\mathrm{s3}}$ He must also show the officer the original or office copy of the judgment or order appealed from, but he leaves no copy of this for filing. The officer then "sets down" the appeal by entering it in the proper list of appeals corresponding to our court dockets. The appeal must be "set down" before the date specified in the notice. The appeal is then heard in its regular order unless leave is obtained from the Court of Appeal for a postponement. The appeal is set down in one of the following four lists of appeal cases: (1) general list (includes appeals from final judgments and applications for a new trial); (2) interlocutory list; (3) separate interlocutory list; ${ }^{84}$ and (4) the special list. On the special list are set down those appeals which, by the consent of the parties, are to be heard before two judges only.

\section{Filing Document on Appeal}

The appellant must file with the Court of Appeal three copies of the following documents, one copy of each being bound together in a set for the use of each judge of the Court of Appeal:

Pleadings

Notice of appeal

Order of judgment appealed from

All necessary affidavits

Judge's notes of evidence

All other documents necessary for the determination of appeal, such as copies of contracts, wills, etc.

These papers are filed one week before the appeal is likely to appear in the daily court paper for a hearing..$^{85}$

\section{Argument on Appeal}

All that remains is the delivery of the argument on appeal by the barristers retained by the respective parties. No briefs are filed for the use of the appeal judges. The argument is interrupted frequently by questions from the bench, and there is no time limit to the argument. At the close of the argument, the judges confer without leaving their seats and then deliver their decisions orally. The oral decision of each judge as tran-

\footnotetext{
83 Order 58, rule 8.

84 Appeals from certain interlocutory orders are set down for hearing in a separate list. They are listed in ANNUAL PRACTICE (1928) 1201.

8j See Annual Practice (1928) 1200.
} 
scribed by the official court reporter forms the opinions found in the written reports. ${ }^{.5}$

\section{Judge's Notes on Appeal}

There are many difficulties and technicalities connected with the system usually employed under the American practice of bringing the oral evidence before the appellate court. The English system is simplicity itself. As explained before, the judge takes notes of the evidence and his notes unaltered in any way are given to the judges of the Court of Appeal.st The appealing party brings the notes up by filing a "bespeak" with the clerk to the trial judge with a certificate signed by counsel that the notes are necessary for the determination of the appeal..$^{\text {.5 }}$ The clerk then transmits the judge's notes to the Court of Appeal. As intimated above, one or both parties in some cases employ a stenographer to take down the evidence. The Court of Appeal has permitted reference to such notes when there is an ambiguity in the judge's notes or where the judge's notes are not complete.so If the trial judge at the beginning of trial consented that stenographer's notes should be taken in place of his notes, then the stenographic transcript forms the record of evidence on appeal, and the expense of such notes will be allowed as costs on appeal.90 Except for this situation these costs are rarely allowed. ${ }^{92}$ The Court of Appeal has ruled that, if the trial judge took notes, it is improper for the parties even by mutual consent to deprive the court of the use of such notes by substituting a stenographic report. ${ }^{92}$ The court further stated that the judge's notes, supplemented by notes of counsel, should give a sufficient report of the evidence for the determination of the appeal. ${ }^{93}$ It seems that the junior counsel regularly takes notes of the evidence. ${ }^{\text {s }}$

\section{Stenographic Notes of the Judge's Summing $U p$}

If the appellant claims error in the trial judge's summing

\footnotetext{
${ }^{86}$ See Higgins, op. cit. supra note 32 , at 226.

87 Order 58, rule 11 (b).

88 For form of the "bespeak" and counsel's certificate of necessity, see YEARLY PRACTICE (1928) 1179.

${ }^{89}$ Orr Ewing \& Co. v. Johnston \& Co., 13 Ch. D. 484,450 (1879).

${ }^{30}$ Seal v. Turner, supra note 34; Herbert v. Royal Society of Medicine, 56 Sol. J. 107 (1911).

${ }^{31}$ Seal v. Turner, supra note 34; Earl de la Warr v. Mriles, supra note 35.

92 Yorkshire Laundries, Ltd. v. Prickles, [1901] W. N. 20.

${ }^{93}$ Earl de la Warr v. Miles, supra note 35 , at 81 .

94 In Pilling v. The Joint Stock Institute, Ltd., 73 L. T. 570 (1896), Lindley, L. J., said that counsel would have no need of stenographic notes of the evidence, as the notes taken by themselves should be sufficient for their own use.
} 
up to the jury, or in the oral judgment delivered, stenographic notes of these provided by one of the parties will be admitted on appeal and the expenses involved allowed as costs, as no other record of these trial proceedings are available. ${ }^{05}$

\section{Cross-Appeals}

The respondent who wishes to have the judgment varied in his favor is not required to serve formal notice of cross-appeal on the appellant, but he should inform the appellant or other parties affected of his intention to seek a variance in the judgment. ${ }^{\circ 6}$ His failure to do so does not destroy the power of the Court of Appeal to vary the judgment or order at the instance of the respondent, but the court may, in its discretion, adjourn the hearing on appeal with costs against the respondent if it thinks the appellant has been unduly surprised.97

\section{Stay of Excecution}

An appeal does not, as in some American jurisdictions, act as an automatic stay of execution. The appellant seeking such a stay must apply to the trial court, and if refused, to the Court of Appeal.9s In the latter case, notice must be given to the other party that a motion for a stay of execution will be made..$^{n 9}$ As a general rule execution will be stayed only if the appellant proves by affidavit that, if the judgment is paid, he will be unlikely to recover the payment in the event that the appeal is successful, ${ }^{100}$ the matter being entirely within the discretion of the court.

\section{Security for Costs}

The appellant is not required in the ordinary situation to give security for costs. ${ }^{201}$ The respondent may, after first requesting the appellant to provide security, and receiving a refusal, apply to the Court of Appeal for an order directing the appellant to

${ }^{95}$ Pilling v. Joint Stock Institute, Ltd., supra note 94 ; In re de Falbo, [1901] 1 Ch. 523, 543; In re Midland, 41 Ch. D. 476,493 (1889). Cf. Huddleston v. Farness Ry., 43 Sol. J. 295 (1899).

${ }^{\circ 5}$ Order 58, rule 6. For form of this notice see Cintry, op. cit. supra note 54, at 615 . The notice must be served eight days before the hearing in case of an appeal from a final judgment, but only two days before the hearing on an appeal from an interlocutory order. Order 58, rule 7; Jaeger's Sanitary Woolen System Co. v. Walker, 41 Sol. J. 695 (1897). ${ }^{07}$ Order 58 , rule 6.

88 Order 58 , rule 16.

99 For form of notice see CHITTY, op. cit. supra note 54, at 614 .

100 The Annot Lyle, 11 P. D. 114 (1886); Barker v. Lavery, 14 Q. B. D. 769 (1885).

101 Order 56, rule 15. 
furnish such security. ${ }^{102}$ The Court of Appeal will do so only in special circumstances. ${ }^{103}$ It should be noted that the trial court has no jurisdiction to grant this order.

\section{CONCLUSION}

While students of American law reform would do well to study many aspects of English appellate procedure, it is doubtful whether any state will adopt the English system in its entirety. Critical observer's have pointed out that American conditions are very different from those that obtain in England. ${ }^{108}$ Although this is true, it should be remembered that the English system with slight modifications seems to function very well in Ontario, ${ }^{105}$ where conditions are more analogous to those of the United States than to those of England. This, coupled with the fact that many features of English pleading and trial practice have been adopted successfully in some states, suggests that the adoption of the English appellate system in whole or in part would materially improve the efficiency of appellate procedure in the United States.

102 Order 58, rule 15; The Constantine, 4 P. D. 166 (1879). Notice of the application must be served on the opposite party. For form of notice, see CHITTY, op. cit. sicpra note 51, at 613 .

${ }^{103}$ Such as the poverty of the appellant, Hall v. Knowden \& Co., [1899] 1 Q. B. 593; the fact that the appellant is out of the jurisdiction, In re Indian Mining Co., $22 \mathrm{Ch} . \mathrm{D} .83,85$ (1852); or the fact that appellant failed to pay the costs of the action below, Clarke v. Roche, 2 W. R. 309 (1877).

304 A few of the English conditions at variance with those of the United States are: the concentration of most of the nation's important litigation at one place, London; the division of the bar into barristers and solicitors; the high costs taxed in England in furtherance of the idea that the courts should be self-supporting; the high salaries paid the English judges, ete. See Taft, Possible and Necded Reforms in Administration of Justice in Federal Courts (1922) 8 A. B. A. J. 601, 606; Loring, Proccdure in English High Court of Justice and Obstacles to Adoption Here (1022) 8 A. B. A. J. 609; Higgins, op. cit. supra note 32.

10: Section 27 of the Ontario Judicature Act (1913) and Rule of Court 232 give the Ontario appellate court the same extensive povers as those given to the English Court of Appeal. The practice on appeal is very similar. See $\$ \$ 24-31$ of the Ontario Judicature Act, and Rules of Court 492-509. But evidently notes of the evidence are taken by oflicial court stenographers and not by the judges as in England.

For concise descriptions of the Ontario trial and appellate practice, sce Riddell, The Judiciary and the Administration of Justice in the Province of Ontario (1922) 6 Asr. JUD. Soc. J. 6; Amram, Canadian Side-Lights on Prospective Changes in Pennsylzania Procedure (1914) 62 U. of PA. L. REv. 269. 